the following countries: fourteen in Great Britain, three each in France and Switzerland, and one each in Germany and the Netherlands.

\section{Second International Congress on Acoustics, Cambridge, Massachusetts}

THE Second International Congress on Acoustics will be held during June 17-23 in Cambridge, Massachusetts-at Harvard University and the Massachusetts Institute of Technology. At the same time the Acoustical Society of America will hold its fiftyfirst meeting. The Congress is sponsored by the International Commission on Acoustics, which is part of the International Union of Pure and Applied Physics. The main programme of the Congress will be based on three themes: bioacoustics and noise control-human responses to sound (including hearing, psychological response and biological effects) and methods of noise control based on these responses; architectural and musical acoustics-the production of music and speech sounds and the design of enclosures for good conditions of hearing; and physical acoustics and sonics-acoustical studies of matter, propagation of sound, and application of acoustical techniques to technical problems. There will be special demonstrations of speech analysis and synthesis, and a number of exhibits by scientific, technical and manufacturing organizations. Further information can be obtained from the secretary of the Congress, John A. Kessler, Acoustics Laboratory, Massachusetts Institute of Technology, Cambridge, Mass.

\section{The Night Sky in June}

NEw moon occurs on June 8d. 21h. 29m., U.T., and full moon on June $23 \mathrm{~d} .06 \mathrm{~h}$. $13 \mathrm{~m}$. The following conjunctions with the Moon take place: June Id. 00h., Mars $8^{\circ}$ S.; June 7d. I8h., Mercury $5^{\circ}$ S.; June 10d. 05h., Venus $3^{\circ}$ N. ; June 13d. 15h., Jupiter $7^{\circ}$ N.; June 20d. 11h., Saturn $3^{\circ}$ N.; June 29d. 14h., Mars $10^{\circ} \mathrm{S}$. In addition to these conjunctions with the Moon, Mercury is in conjunction with Aldebaran on June 23d. 08h., Mercury $2 \cdot 5^{\circ} \mathrm{N}$. Mercury is too close to the Sun during the greater part of the month for observation, but at the end of the month it rises at $2 \mathrm{~h}$. $45 \mathrm{~m}$... an hour before sunrise-and may be seen for a short period, its brightness being greater than that of a first-magnitude star. Venus sets at $23 \mathrm{~h} .30 \mathrm{~m}$. at the beginning of June, but draws closer to the Sun and on June 30 sets only half an hour after sunset; its stellar magnitude varies from $-4 \cdot 1$ to $-3 \cdot 4$, and the visible portion of its illuminated disk decreases from $0 \cdot 140$ until it is in inferior conjunction with the Sun on June 22d. 06h. Mars rises at 0h. $45 \mathrm{~m}$., 0h. $10 \mathrm{~m}$. and $23 \mathrm{~h}$. $25 \mathrm{~m}$. on June 1,15 and 30 , respectively, and has an eastward movement in Aquarius; it increases in brightness during the month owing to a small increase in the visible portion of its illuminated disk and also to its distance from the Earth decreasing from 76 to 58 million miles. Jupiter, visible soon after sunset, sets at $0 \mathrm{~h} .25 \mathrm{~m} ., 23 \mathrm{~h} .30 \mathrm{~m}$. and $22 \mathrm{~h}$. $40 \mathrm{~m}$. on June 1,15 and 30 , respectively ; its stellar magnitude varies between $-1 \cdot 5$ and $-1 \cdot 4$ owing to its distance from the Earth increasing from 520 to 557 million miles. Towards the end of the month it is close to Regulus. Saturn, in Libra, sets in the early morning hours-at $3 \mathrm{~h} .30 \mathrm{~m}$. on June 1 , one hour earlier on June 15 and two hours earlier on June 30 ; its stellar magnitude varies from 0.3 to
0.5 owing to its distance from the Earth inereasing by 20 million miles. No occultation of stars brighter than magnitude 6 occur in June. Summer solstice occurs on June 21 d. $10 \mathrm{~h} .24 \mathrm{~m}$., and the total time of sunshine in the latitude of Greenwich is then approximately $16 \mathrm{~h} .40 \mathrm{~m}$. A total eclipse of the Sun occurs on June 8 and is visible as a total eclipse only in the South Pacific Ocean, maximum duration 4m. 45s.; it will be soen in New Zealand at sunrise as a partial eclipse.

\section{Announcements}

Dr. LLOXd P. SMith, at present chairman of the Department of Physics of Cornell University, has been appointed president of the Research and Advanced Development Division and vice-president of the Avco Manufacturing Corporation, of New York. The Corporation manufactures a wide range of electrical and electronic goods, including defence equipment for the United States Government.

THE Ford Foundation has given two grants of 4,250 dollars $(£ 1,517)$ each to the University of Cambridge to assist the work of Prof. M. Fortes, William Wyse professor of social anthropology, and of Mr. E. R. Leach, lecturer in the Department of Archæology.

THE following three new members have been appointed to the Board of Regents of the Smithsonian Institution, Washington, D.C.: Dr. E. L. DeGolyer, a petroleum geologist and senior member of the firm of DeGolyer and McNaughton, Dallas, Texas ; Dr. C. H. Greenewalt, a chemical engineer and president of E. I. du Pont de Nemours and Co.; Dr. C. P. Haskins, a research biologist and president of the Carnegie Institution of Washington. The Board of Regents of the Smithsonian Institution is by law composed of the Vice-President of the United States, the Chief Justice of the United States, three members of the Senate, three members of the House of Representatives, and six citizen members.

THE second display of instruments, organized by the Scientific Instrument Manufacturers' Association at the Instrument Centre, 20 Queen Anne Street, London, W.1, was opened on May 22 and will continue for three months.

The Hydrocarbon Research Group of the Institute of Petroleum is arranging a symposium on "Vapour Phase Chromatography" during May 30-June 1, to be held at the Institution of Electrical Engineers, Savoy Place, London. During the meetings there will be an exhibition of apparatus. Further information can be obtained from the organizing secretary and trcasurer, Mr. H. C. Rampton, c/o The British Petroleum Co., Ltd., Chertsey Road, Sunbury-onThames, Middlesex.

As exhibition of fishery equipment, including echo-sounders, has been arranged in connexion with the fourth meeting of the General Fisheries Council for the Mediterranean, to be held in Istanbul during September 17-22 (see Nature, May 5, p. 831). Exhibition space will be available, free of charge, and special arrangements have been made for the temporary import, duty free, of equipment for display. Firms wishing to exhibit equipment should write, before July 15, to Mr. Cihat Renda, Meat and Fish Office (Et ve Balik Kurumu Umum Müdürlügü), Selanik Cad. 78, Ankara, from whom further information can be obtained. 